\title{
Comparison and Co-existence: \\ Sources and Purpose of Authority in the Australian, Madayin and Talmudic Legal Systems
}

\author{
Claire Powel1* \\ Charles Darwin University School of Law, Darwin, Australia
}

\begin{abstract}
This article will compare Australian, Madayin and Talmudic law in terms of their respective sources and purposes. It will focus on the characterisation of each system to highlight conceptual similarities and differences which affect their operation and,in particular, their commensurability with other systems. Specific areas of law concerned with coexistence are identified as being both crucial and particularly problematic. Notwithstanding Australian government statements and High Court rulings asserting the sovereignty of Australian law, it will be argued that no legal system is self-contained. Accommodations are essential and require legislators to grapple with the difficulties of reconciling differing conceptualisations using an informed comparative framework. Talmudic law is considered here as an example of a system which has demonstrated the ability to coexist adaptively with a variety of other systems without compromising its integrity.
\end{abstract}

Keywords: Australia, Indigenous, Talmudic, Law, Co-existence.

How to Cite: Powell, Claire. 2017. "Comparison And Co-Existence: Sources And Purpose Of Authority In The Australian, Madayin And Talmudic Legal Systems". Udayana Journal Of Law And Culture 1 (2): 141-156. doi:10.24843/UJLC.2017.v01.i02.p04.

DOI: https://doi.org/10.24843/UJLC.2017.v01.i02.p04

Copyright (C) 2017 UJLC. All right reserved

\section{Introduction}

The continuing assertion of the unitary nature of the Australian legal system has perpetuated an antagonist relationship with Aboriginal systems of law since colonisation. ${ }^{1}$ However, it is generally accepted that customary international law requires acknowledgement of the rights of indigenous people to 'regulate autonomously their internal affairs according to their customary law and to establish, maintain and develop their own legal and political institutions, in a way that is consistent with the rules on fundamental human rights' and that '(s)tates have the obligation to recognize

* Correspondence: s249223@students.cdu.edu.au.

1 On the application of Australian law to the Aboriginal population see $R v$ Jack Congo Murrell (1836) 1 Legge 72; on the unitary nature of Australian law see Kruger v Commonwealth (1997) 190 CLR 1. More recent High Court rulings, particularly concerned with the influence of international law have reaffirmed the sovereignty of Australian law, see CPCF $v$ Minister for Immigration and Border Protection [2015] HCA 1 at 211 . 
and ensure respect for the laws, traditions and customs of indigenous peoples. ${ }^{2}$ The extended negotiation process leading to Australia's eventual acceptance of the UN Declaration of the Rights of Indigenous Peoples demonstrates the deep-rooted reluctance to deviate from this position and highlights the view of successive Australian governments and the High Court of the sovereignty of Australian law. ${ }^{3}$ In so far as substantive acknowledgement of specific Indigenous legal rights does exist, for example in relation to land rights and culturally appropriate education, it has been hard won and framed more in terms of concessions than rights. ${ }^{4}$

Talmudic law by contrast provides an unusual example of a legal system, which is fundamentally pluralistic. ${ }^{5}$ It has endured, successfully operating in parallel with a highly diverse range of other legal systems, for more than two thousand years and is used here to highlight the scope of possibilities for effective accommodation between systems with seemingly antithetical legal concepts. The analysis in this article suggests future avenues for research to facilitate this process of accommodation both in Australia and elsewhere, particularly in jurisdictions where indigenous systems of law are evident.

\section{Result and Discussion}

\subsection{Australian Legal System}

The Australian Constitution (the Constitution) is the foundational source of the Australian legal system authorising the division and exercise of power 'to make laws for the peace, order, and good government'6 of the nation. Unlike chthonic systems of law, Australian law is formally independent of other sources of authority, including religious and moral authority, although the influence of the Christian tradition in the inception of Australian law is evident from the Preamble to the Constitution 'relying on the blessing of Almighty God.' As McKennna, Simpson and Williams have observed, however, the framers, recognising the interpretative potential of including those words, were careful to reject any particular or direct religious authority, preserving religious neutrality under the provisions of $\mathrm{s} 116 .^{7}$ The development of

2 International Law Association, The Hague Conference (2010) Rights of Indigenous Peoples 74 International Law Association Report Conference, 834 2010, 910.

3 See Minister for Immigration and Ethnic Affairs $v$ Teoh (1995) 183 CLR 273 at 287 per Kirby, J and other immigration law rulings on the influence of international law and human rights law on Australian law for example CPCF v Minister for Immigration and Border Protection [2015] HCA 1.

4 Mabo $v$ Commonwealth (1992) 175 CLR 1; Wik Peoples $v$ Queensland (1996) 187 CLR 1; on culturally appropriate education and specifically use of Aboriginal languages in education see Calma, Tom,"Sustaining Indigenous Education, Language and Culture", speech delivered at World Indigenous People's Conference: Education on 9 December 2008.

5 Menachem Elon (i), "Law, Truth, And Peace: 'The Three Pillars Of The World', New York University Journal of International Law \& Politics 19 (1996), 440.

6 Australian Constitution,s61 for example.

7 Mark McKenna, Amelia Simpson and George Williams, "First Words: The Preamble To The Australian Constitution," University of New South Wales Law Journal 24 (2001), 386; Australian Constitution, s116 "The Commonwealth shall not make any law for establishing any religion, or for imposing any religious observance, or for prohibiting the free exercise of any religion, and no religious test shall be required as a qualification for any office or public trust under the Commonwealth." 
Australian law continues to be shaped by prevailing social norms, including religion and morality as will be discussed below.

The scope of Australian law is clearly defined according to specific areas of human action, including primarily administrative law, constitutional law, contract law, criminal law, environment and planning law, equity, family law, property law and tort law. Law, subject to constitutional consistency, is sourced from both case law by means of a system of legal precedent and legislation made in Parliament. There is a formal separation of powers into the Legislature, Executive and Judiciary. Case law is subordinate to legislation, according to the operation of the doctrine of parliamentary supremacy. ${ }^{8}$ A hierarchy of courts throughout Australia has enabled the development of a single common law.

Ultimate control of the legal system lies with the citizenry through a chain of responsibility, which is known as responsible democracy, ${ }^{9}$ whereby the government 'is chosen by, accountable to, and owes its continued existence to, the legislature, ${ }^{10}$ whose representatives are democratically elected by the citizenry according to the provisions of the Constitution. ${ }^{11}$ The Constitution itself may only be altered by the domestic legislature with the approval of the majority of citizens in the majority of states by means of referendum. ${ }^{12}$ The purpose of the Australian legal system has therefore been described as enabling the demos to rule. ${ }^{13}$ Other commentators have stressed the continuing acceptance of the Constitution 'as fundamental legal rules of [the] system and the basic constitutive documents of [the] community', ${ }^{14}$ its Grundnorm. ${ }^{15}$

\subsection{Madayin}

Madayin (or Ngarra ${ }^{16}$ ) operating in North-East Arnhem land is wholly integrated with the overall philosophy of the Yolngu, who in habit that land. Until very recently

8 A.V. Dicey, Introduction to the Study of the Law of the Constitution (Indianapolis, Liberty Classics, first published 1885, 8th ed, 1915, reprint 1982), cxlviii.

9 Theophanous $v$ Herald and Weekly Times (1994) 182 CLR 104.

10 John McMillan, Gareth Evans and Haddon Storey, Australia's Constitution: Time for Change? (Sydney: Law Foundation of New South Wales and George Allen \& Unwin Australia, 1983), 209.

11 Australian Constitution, ss 7, 24.

12 Ibid, s 128.

13 Danial Kelly (i), "The Legal and Religious Nature of Aboriginal Customary Law: Focus on Madayin", University of Notre Dame Australian Legal Review 16 (2014), 73.

14 Leslie Zines, Constitutional Change in the Commonwealth. (Cambridge: Cambridge University Press, 1991), 27 and see John Quick and Robert Garran, The Annotated Constitution of the Australian Commonwealth (Sydney: Angus and Robertson, first published 1901, 3rd ed 1995), 988 'In the Constitution of the Commonwealth 'of course there is no absolute sovereignty, but a quasi-sovereignty which resides in the people of the Commonwealth. who may express their will on constitutional questions through a majority of the electors voting and a majority of the States.'

15 Hans Kelsen, Pure Theory of Law, Legality and Legitimacy (Oxford: Oxford University Press, 2007), 56.

16 George Pascoe Gaymarani, "An Introduction to the Ngarra Law of Arnhem Land”, Northern Territory Law Journal 1 (2011), 283. 
no legal authorities had been in written form, but were rather completely oral. ${ }^{17}$ The need to provide a written record of the law to enable it to be interpreted by Australian lawmakers and academics has now been recognised. ${ }^{18}$

According to the Yolngu there is no separation from law, it has been there since time immemorial 'when the world was nothing...(the) law created this country'. ${ }^{19}$ It is believed to have been embedded in the landscape and its inhabitants by a mythical being (Wangara), ${ }^{20}$ governing every facet of existence to maintain a state of Magaya, where there is peace, harmony and order, ${ }^{21}$ and where all life may flourish. It includes sacred places and objects such as art works, songs and ceremonies associated with the law.

Magaya is achieved by means of obligatory ceremonies, which reinforce the ascribed relationships between and among individuals and the land they inhabit and most fundamentally through the practice of a fertility philosophy. ${ }^{22}$ It has been described as a theocracy in the sense of government by deity as interpreted by ecclesiastical authorities. ${ }^{23}$

\subsection{Talmudic Law}

The Talmudic system also represents a comprehensive, existential philosophy prescribing conduct in all areas of life. Halakhah, translated as the way or path to walk, captures this sense, referring to that portion of the Talmud which deals with the law. ${ }^{24}$ Sources of authority are in both written and oral form and it is believed that the entire Talmud is derived from God and revealed to Moses. ${ }^{25}$ Although Judaism predates Moses, the reception of the law is taken to be the beginning of Talmudic law. ${ }^{26}$ The written sources are vast, complex in their interrelatedness and multi-layered, although not necessarily hierarchically according to their respective degree of authority. The initial process of writing the Talmud was undertaken as a protective measure in response to the diaspora and consequent loss of political sovereignty, as a means of

17 Ibid., 284.56.

18 Danial Kelly (ii), "Foundation Sources and Purposes of Authority in Madayin”, Victoria University Law \& Justice Journal 4 (2014), 48.

19 Gaymarani, op.cit., 245.

20 Kelly(ii), op.cit., 49.

21 Gaymarani, op.cit., 286.

22 Kelly(ii), op.cit., 52.

23 Ronald M. Berndt, An Adjustment Movement in Arnhem Land, Northern Territory of Australia (Paris: Cashiers de L'Homme, Mouton), 1962) 14.

24 Encyclopaedic Australian Legal Dictionary, http://www.lexisnexis.com.ezproxy.cdu.edu.au/au/ legal/results /enhdocview.do?docLinkInd=true\&ersKey=23_T25738853566\&format=GNBFULL\&startDocN $\mathrm{o}=0 \&$ resultsUrlKey=0_T25738853569\&backKey=20_T25738853570\&csi=267785\&docNo=2\&fromDocPrevi ew $=$ true \&scrollToPosition $=0$.

25 8th Principle, From the 13 Principles of Faith, Maimonides, That we believe that the entire Torah which we possess today is the Torah given to Moses, and that it was given in its entirety by the Almighty.

26 H. Patrick Glenn, Legal Traditions of the World (Oxford: Oxford University Press, 3rd ed, 2007), 94. 
safeguarding the law. ${ }^{27}$ The fundamental basis of Talmudic law is the Pentateuch, referred to as the Torah, which may also signify the entirety of Talmudic law. ${ }^{28}$

The Mishnah comprises a collection of legal rules derived through interpretation of the Torah by sages and arranged in volumes according to their subject matter. The volumes are entitled Zera'im (Seeds): concerning prayer and agriculture; Mo'ed (Festival) concerning holy days; Nashim (Women) containing the laws concerning marriage and divorce; Nezikin (Damages), covering civil and criminal law; Kodashim (Holy Things), encompassing temple rituals, sacrifices and dietary laws; and Toharot (Purities), delineating the laws of ritual purity and impurity.

The Jerusalem and Babylonian Talmuds were the first written records of debates and opinions on the Mishnah and remain the basic books of law equivalent to customary law. Each version has enjoyed different relative levels of authority historically. It has been argued that the Talmud is of higher authority than the Torah and that even God is bound by customary law. ${ }^{29}$ Subsequent to the Talmud a body of written responsa has developed recording learned rabbinical opinion with biblical authority on the application of the law. ${ }^{30}$

The oral tradition, which began with Moses interpreting the Torah, is considered divine and has been continued by adherents through a process of repetition and rote learning, as an obligatory practice. ${ }^{31} \mathrm{Much}$ of the oral law has been translated into written form, as outlined above. Elon describes the Torah and the body of oral law as the Grundnorm of Talmudic law and the subsequent responsa as constituting the case law. ${ }^{32}$

The overall purpose of Talmudic law is encapsulated by the concept of Halakhah, whereby practice is directed to enhancing well-being and refining humanity. ${ }^{33}$ The primary imperatives, derived from authoritative Talmudic sources, are law, truth and peace. ${ }^{34}$ Commentators have also identified the restoration of harmony, drawing

27 Ibid., 98.

28 Ibid., 95.

29 Bava Metzia 59a-b (the Oven of aknai) where Rabbi Joshua disputing a heavenly voice claims "It is not in Heaven"; God replies "My children have defeated Me...."

30 Deut.17:9 "Go to the priests, who are Levites and to the judge who is in office at that time. Inquire of them and they will give you the verdict."

31 Maimonides, Introduction to the Talmud, Trans, and Annot. Z Lampel (New York: Judaica Press, 1975), 35.

32 Menachem Elon(ii), "The Legal System of Jewish Law”, New York University Journal of International Law \& Politics17 (1984), 229-230.

33 Emunot VeDeot, Saadia Gaon (Babylon/Iraq 900 CE), The Guide for the Perplexed; Moses Maimonides (Spain/North Africa 1200 CE); Midrash Bereishit Rabbah 44.

34 For example, Menachem Elon (i) focuses on these Imperatives Emanating From the Talmud for Example in the Mishnah [M] Avot 1:18, quoting Zechariah 8:16. 
parallels with other chthonic systems, such as Madayin ${ }^{35}$ and similarly the affirmation of the love of God, ${ }^{36}$ echoing the ceremonial practices of Yolngu.

\subsection{Comparison of Key Characteristics in the Three Systems}

The foundational separation of law from other systems of authority in the Australian legal system contrasts sharply with the integration of Madayin and Talmudic law with the whole social order. It conforms closely to Mattei's rule of professional law, ${ }^{37}$ resting on the 'supposition that law constitutes an autonomous body of rules independent and separate from, although not uninfluenced by, religion, morality, and other social norms.' In this sense and formally it is a predominantly positive law system, although in practice the application of precedent in common law systems relies on the acknowledgement of community standards, thus weakening its positivistic basis. ${ }^{38}$ This is quite unlike Madayin law based firmly on natural law and controlling the whole social order, including religion, culture and politics, which conforms to Mattei's conception of rule of traditional law. ${ }^{39}$ It not only defines and enforces relationships between people, with nature and with the divine ${ }^{40}$ but also prescribes the rules of social order and practice, including education, child-rearing, sexual relations and marriage. ${ }^{41}$ Talmudic law also has a theocratic basis but reflects a separation from autochthony as monotheism assigns people the role of law making in partnership with the divine. ${ }^{42}$ Thus, although clearly a natural law system, with no separation of the religious and cultural from law, secular authority to legislate has been clearly recognised at least since medieval times. The substance of the law, however, remains in rabbinical control. ${ }^{43}$ Laws are categorised as either issura, concerning religious law, which includes matters of family law, such as marriage and divorce, and ritual matters, or mamona, concerning secular matters, including most civil and criminal law. Issura law is strictly rabbinically controlled. while mamona is amenable to the application of secular authority. However, as most law has an

\footnotetext{
35 Glenn, op.cit., 99.

36 Ibid., 104.

37 Ugo Mattei, “Three Patterns of Law: Taxonomy and Change in the World's Legal Systems",
} American Journal of Comparative Law45(1997), 31.

38 Joseph Dainow, "The Civil Law and the Common Law: Some Points of Comparison”,The American Journal of Comparative Law15 (1966), 425.

39 Ibid.,35.

40 Ronald. M Berndt, "A Profile of Good and Bad in Australian Aboriginal Religion", Charles Strong Memorial Lecture 1979 reprinted from Colloquium Journal of the Australian and New Zealand Society for Theological Studies, 18.

41 Gaymarani, op.cit,. 288.

42 As God placed creation in Adam's hands with the instruction to 'rule over it' Genesis 1:28-30. The Talmud also instructs people to work and protect; to complete the process of creation; and to partner with God.

43 See for example, Maimonides, Yad, at Gezelah 5:14 'The principle of the matter is the following: any law that the king will enact which applies generally and not only to a single individual is not thievery; and whenever he will take from a particular individual only, except by law applicable to everyone, this is unlawful and robbery. 
issura component it remains subject to rabbinical scrutiny and any secular law on issura will be held to be invalid to the extent that it is inconsistent with a Talmudic ritual precept. ${ }^{44}$ Overall it encompasses all areas of law represented in common law systems, including the Australian legal system.

\subsection{Means of Interpretation}

To understand legal authority it is important to consider the accepted means of interpretation. In Australian law judges interpret the law, determine disputes and judge the legitimacy of legislation. If laws are ultra vires, beyond the power of legal authority, they will be struck down as unconstitutional. ${ }^{45}$ Similarly, the rabbis in their judgements and responsa trace a thread of reasoning to Talmudic sources in order to establish validity. ${ }^{46}$ In the Australian system judgement is final (appeals excepted), according to the principle of Res judicata, and is reached on the basis of evidence put by opposing parties, resulting in a winner and a loser. ${ }^{47}$ Madayin and Talmudic law in contrast, aim to re-establish harmony using negotiation processes. The Ngarra court operates in a completely open adjudicative process. ${ }^{48}$ The elders sit to discuss matters of law, to determine policy and also have authority from the Yolngu community, including parties to disputes, to make binding judgements. Judgements are made by male and female clan leaders through open discussion with the parties and their families. Each party is represented and mediators are used and normally a negotiated settlement (makarrata) is reached to which the offender agrees. Rabbinical courts (Bet din), although generally without state authority, are often regarded as decisors settling matters in private law. ${ }^{49}$ They are more concerned with establishing truth than efficiency or stability. ${ }^{50}$ There are no appeal provisions but parties may return to the same court if they consider the initial judgement to be erroneous, thus not recognising Res judicata. ${ }^{51}$ Rabbinical courts in Israel claim to be based on Talmudic law, but in practice they have adopted contemporary procedures. ${ }^{52}$

44 R. Simeon Duran, Responsa (Tashbez) 1:158.

45 Humane Society International Inc v Minister for the Environment and Heritage (2003) 126 FCR 205.

46 David Luban, "The Coiled Serpent of Argument: Reason, Authority, and Law in A Talmudic Tale", Chicago-Kent Law Review 79 (2004), 1286.

47 Dainow,op.cit., 35.

48 Gaymarani, op.cit., 286.

49 Perry Dane, “The Yoke of Heaven", University of Toronto Law Journal 44(1994) 353.

50 Elon(i), loc.cit.

51 Yuval Sinai, "Reconsidering Res Judicata: A Comparative Perspective", Duke Journal of Comparative \& International Law 21 (2010), 365.

52 Jewish Virtual Library, “Encyclopaedia Judaica, Practice and Procedure”,http://www.jewishvirtuallibrary.org/practice-procedure. 


\subsection{Evolution and Adaptation}

Australian law has a fixed starting point at Federation in 1901, though because Australia received English law at the establishment of the colonies, it could be argued that the roots of Australian law extend back through English history. ${ }^{53}$ The Australian constitutional framework has endured since Federation, preserving its core precepts, while adapting to changing social circumstances, technical advances and the influence of precedent. ${ }^{54}$ Australian law is described as sovereign rather than eclectic, a characteristic evoked repeatedly by opponents of the recognition of Aboriginal customary law. ${ }^{55}$ The iconoclastic ruling in Mabo cautioned in similar terms, ${ }^{56}$ reflecting the High Court's resistance to accepting any plurality of laws. Nevertheless, the legal system has incorporated elements of Indigenous legal practice, particularly through as an extension of restorative justice programmes, including elements of circle sentencing in several jurisdictions. ${ }^{57}$

Talmudic law is traced to the revelation of the Torah, the Grundnorm of the system. ${ }^{58}$ Since the compilation of the Babylonian Talmud Halakah continued to develop through the responsa, forming a dynamic body of law comparable to case law. ${ }^{59}$ Subsequent exile and the creation of a diasporic Jewish population has precipitated a legal system without fixed geographical jurisdiction. A massive volume of responsa material has developed through the application and adaptation of Talmudic law to local social and economic conditions, leading to the development of new substantive areas of law concerned with, for example, public administration, tax and criminal justice. ${ }^{60}$

In exile Jewish communities were generally empowered to resolve internal legal disputes by the respective jurisdictional government. ${ }^{61}$ That recognition has ceased

53 Geoffrey Lindell (i), "Why Is Australia's Constitution Binding?: The Reasons In 1900 and Now, and The Effect of Independence", Federal Law Review 6 (1986), 29.

54 See Geoffrey Lindell (ii), "Expansion or Contraction? Some Reflections About the Recent Judicial Developments on Representative Democracy", Adelaide Law Review20 (1998), 111-146; Amelia Simpson and George Williams, "International Law and Constitutional Interpretation", 11 PLR 205.

55 Australian Law Reform Commission, "Recognition of Aboriginal Customary Laws", Report No. 31, 12 June 1986, paragraph 118. Divisiveness and the 'One Law'. A view strongly stated in several submissions was that recognition would create an undesirable form of legal pluralism, and that it would be divisive or an affront to public opinion. Proponents of these views argue that there should be 'one law for all,[59] and that the goal should be 'social equality for Aborigines within the concept of racial unity and integration'.

56 Mabo v Queensland (No 2) (1992) 175 CLR 1 at 29 'In discharging its duty to declare the common law of Australia, this Court is not free to adopt rules that accord with contemporary notions of justice and human rights if their adoption would fracture the skeleton of principle which gives the body of our law its shape and internal consistency.'

57 See for example Richards, Kelly. 'Police-referred Restorative Justice for Juveniles in Australia' [online]. Trends and Issues in Crime and Criminal Justice, No. 398, Aug 2010: [1]-8, http://search.informit. com.au.ezproxy.cdu.edu.au/documentSummary;dn=846094200631694;res=IELHSS.
58 Kelsen, loc.cit.
59 Elon(i), op.cit., 239.
60 Ibid., 233
61 Ibid., 231. 
since the process of emancipation in the 18th century, whereby Jews have been accorded the same rights and responsibilities as other members of society. However, the development and influence of Talmudic law has continued, including the parallel operation of rabbinical courts alongside state civil courts, authorised in Israel to adjudicate personal law matters. ${ }^{62}$

It is understood that Madayin has been in existence since time immemorial, but is nevertheless a dynamic system, open to influence from Australian law, syncretic and also relative in that there are generally no hard and fast rules. Commentators have observed that chthonic systems are by their nature dynamic, internally contested and syncretic, immersed as they are in their respective landscapes. ${ }^{63}$ No indigenous system, including Madayin, exists in an autonomous jurisdiction and therefore their authorities and practices develop in response to an evolving relationship with the overarching polity and changing social conditions and attitudes.

\subsection{Co-existence With Other Legal Systems}

The ability to accept, or at least recognise, alien sources of authority is challenging for all sovereign states. Since R $v$ Jack Congo Murrell (1836) 1 Legge 72 it was taken to be settled in principle that Australian law applies to the Aboriginal population. England chose to weaken the erst while chthonic law by imposing its law on the indigenous population. This has not been the case uniformly in other parts of the world. Glenn, for example, cites Ghana, where the colonising English strengthened pre-existing chthonic law providing constitutional recognition. ${ }^{64}$ Several states in South America now practise well-developed systems of legal pluralism with special jurisdictions of indigenous law ${ }^{65}$ recognised in the constitutions of Peru, Bolivia, Ecuador and Venezuela since the 1990s, including the right to administer justice in their own territories. These developments reflect an international trend to recognise indigenous dispute resolution practices to address the acknowledged inequities in the justice systems. ${ }^{66}$

Failure to recognise customary law in the Australian legal system continues to result in significant injustice to the Aboriginal population as a consequence of

62 Foundations of Law 5740-1980, Sefer Ha-Chukim No. 978 at 163 (July 31, 1980) (official collection of statutes of the State of Israel).s48 Where a court is required to decide a legal question for which there is no answer in statutory law, judicial precedent, or by analogy, the question shall be determined in the light of the principles of freedom, justice, equity, and peace of the Jewish heritage.

63 Rachel Sieder, "The Challenge of Indigenous Legal Systems: Beyond Paradigms of Recognition", Brown Journal of World Affairs 18 (2012), 106; Glenn, op.cit., 78.

64 Glenn, op.cit., 82.

65 Sieder, op.cit., 3.

66 Ibid., 104. 
differing conceptions of legal relations and responsibility, particularly where customary law governs conduct. A Yolngu person's place in the universe is ascribed with clear, inescapable duties and responsibilities to other people according to kinship relations. ${ }^{67}$ Yolngu also share corresponding responsibilities to "preserve critical order of the natural world' ${ }^{\prime 68}$ of which they are an integral part by caring for country. They construe their position as entailing obligations rather than rights, a concept that has developed from individualistic, property-based legal systems, such as the Australian system.

Glenn discusses the incompatibility of chthonic systems of common ownership with property law, ${ }^{69}$ problems which have been highlighted in the area of copyright for art works. ${ }^{70}$ Under Aboriginal law traditional owners are responsible for any unauthorised reproduction of sacred objects, even where they may have no direct control of that occurrence, and are liable to severe punishment. Attention has also been drawn to the risks of ignoring Aboriginal conceptions of responsibility in the area of criminal law. In the case of a fatal car accident Australian law assigns responsibility to the driver of the vehicle but under customary law all occupants of the car and the driver's close kin would be held responsible for failing to keep the driver safe. ${ }^{71}$

The High Court's ruling that Aboriginality is irrelevant to the sentencing process $^{72}$ means that Aboriginal plaintiffs are judged disregarding their customary obligations and they may misunderstand the charges against them pleading inappropriately as a consequence, a situation exacerbated by the paucity of appropriate legal services. ${ }^{73}$ The ruling may also be seen as being antithetical to the rule of law and contrary to international law. ${ }^{74}$ Recommendations of the Australian Law Reform

\footnotetext{
67 Gaymarani, op.cit., 290-5.

68 Edward Goldsmith, The Way: An Ecological Worldview (London: Random Century, 1992) xi-xvii.

69 Glen, op.cit., 61

70 Milpurrurru $v$ Indofurn Pty Ltd (1995) 6 AIPJ 185 para 13.

71 Tatum Hands, "Teaching An Old Dog New Tricks: Recognition of Aboriginal Customary Law in
} Western Australia", Indigenous Law Bulletin6 (2006), 14.

72 Bugmy $v$ The Queen (2013) 249 CLR 571; [2013] HCA 37.

73 See Chris Cunneen, Fiona Allison, and Melanie Schwartz, "Access to justice for Aboriginal People in the Northern Territory", Australian Journal of Social Issues 49, No. 2 (2014): 219-240, http://search. informit.com.au.ezproxy.cdu.edu.au/documentSummary;dn=453499071087937;res=IELFSC.

74 For example Article 27 of the United Nations Declaration on the Rights of Indigenous People annexed to GA Res 61/295, UNGAOR 61 ${ }^{\text {st }}$ Sess No 49, Vol 111, UN Dox A/61/49 (2008) 15, states: 'States shall establish and implement, in conjunction with indigenous peoples concerned, a fair, independent, impartial, open and transparent process, giving due recognition to indigenous peoples' laws, traditions, customs and land tenure systems, to recognize and adjudicate the rights of indigenous peoples pertaining to their lands, territories and resources, including those which were traditionally owned or otherwise occupied or used. Indigenous peoples shall have the right to participate in this process; and also Universal Declaration of Human Rights, G.A. Res. 217A, Art. 74, U.N. GAOR, 3d Sess., 183d plen. mtg., U.N. Doc. A/810 (Dec. 10, 1948); International Covenant on Economic, Social and Cultural Rights art. 2(3), Dec. 16, 1966, 993 U.N.T.S. 23 
Commission (ALRC) report in $1986^{75}$ and the subsequent Law Council of Australia report in $2006^{76}$ were framed in terms of a need for accommodation. The ALRC concluded that the risks of pluralism can be avoided or minimised and that it was an appropriate response 'for a geographically wide-spread and culturally diverse society. ${ }^{77}$

Yolngu elders generally accept the authority of Australian law $^{78}$ and have demonstrated some willingness to change traditional practices to comply with the requirements of Australian law. Punishments, such as spearing, have been adapted to be symbolic rather than inflicting serious injury and there has been a recognition that the physical punishment of women constitutes domestic violence and is unacceptable. ${ }^{79}$

Talmudic law similarly emphasises the centrality of obligation (Mitvah) rather than rights, in particular to study the law; to fulfill obligations to demonstrate love of God; 80 and to do what is right and good. ${ }^{81}$ Jewish law holds people accountable for any damage they cause, whether intentional or accidental, unless the damage is completely unavoidable. ${ }^{82}$ There is a long history of co-existence with other legal systems and accordingly the principle of dina de-makikhuta dina (the law of the land) accepts the authority of the respective jurisdiction in which Jews are living. ${ }^{83}$ The validity of various provisions of alien legal systems in civil matters is recognised, even if they are contrary to Jewish law. However, the law of the secular authority is not valid if it is inconsistent with an aspect of issura ${ }^{84}$ or infringes the basic concepts of justice, morality, equity and freedom. Contracts have thereby been voided where the debtor agreed to imprisonment for non-payment. Under Jewish law no-one can agree to lose their freedom and laws must apply equally to all members of the community without discrimination. Otherwise a law is considered unlawful and to constitute robbery. ${ }^{85}$ A sophisticated system of mechanisms to deal with conflict of laws has developed, whereby pluralism in debate is condoned in the process of discovering

\footnotetext{
75 Australian Law Reform Commission,loc.cit.

76 Ibid.

77 Ibid., paragraph 118.

78 Ibid.Gaymarani, op.cit., 299-300.

79 Danial Kelly (iii), "The Black and White of Wunungmurra", Northern Territory Law Journal 2
} (2012), 234.

80 See R. Cover, "Obligation: A Jewish Jurisprudence of the Social Order", Journal of Law and Religion 5 (1987), 65 on the superiority of an obligation perspective.

81 Deuteronomy 6:18

82 Authority in the Mishna eg Maimonides, Mishna Torah, Laws of Damager, 6:15.

83 Baba Kamma 113b.

84 Elon(i), op.cit., 223.

85 Ibid., 224. The principle of the matter is the following: any law that the king will enact which applies generally and not only to a single individual is not thievery; and whenever he will take from a particular individual only, except by law applicable to everyone, this is unlawful and robbery' quoting Maimonides. 
the means to achieve uniformity in practice and to maintain the imperative to abide by the spirit of the law. ${ }^{86}$ Rabbis have thus developed lines of reasoning, including elaborate legal fictions, to enable acceptable solutions to be reached. ${ }^{87}$

\section{Conclusion}

This article has highlighted some of the significant similarities and differences in the sources of authority and purpose of Madayin, Talmudic and Australian law. Attention has been drawn to the importance of jurisprudential construction in understanding the operation of these systems, particularly in terms of their different positions on a spectrum from being purely positivist to being wholly based on natural law. In chthonic systems like Madayin and to a lesser extent Talmudic law, a legal wrong by disrupting harmony, inflicts a social wound ${ }^{88}$ and the parties negotiate a solution to reestablish the natural order. The truth is paramount. A wrong in common law systems such as Australian law broadly breaches individual legal rights and the law provides remedies on the basis of contested evidence. This perspective explains the Madayin and Talmudic emphasis on obligations and responsibilities to maintain the natural order compared with the Australian focus on individual rights. Similarities have also been identified, notably that all three systems rely on the mediation of law through respectively elders, rabbis and judges, who trace lines of legal reasoning derived from the relevant authorities. With these observations in mind and considering the geo-political context of each system it is argued that cooperative co-existence is crucial and Talmudic law offers an interesting model for consideration.

\footnotetext{
86 Elon (ii), op.cit., 469

87 Ibid., 456.

88 Glenn, op.cit., 68.
} 


\section{BIBLIOGRAPHY}

\section{Book}

Berndt, Ronald M. An Adjustment Movement in Arnhem Land, Northern Territory of Australia (Paris: Cashiers de L’Homme, Mouton), 1962

Dicey, A.V. Introduction to the Study of the Law of the Constitution. Indianapolis: Liberty Classics, first published 1885, $8^{\text {th }}$ ed, 1915, reprint 1982

Glenn, H. Patrick. Legal Traditions of the World, $5^{\text {th }}$ ed. Oxford: Oxford University Press. 2014

Goldsmith, Edward. The Way: An Ecological Worldview, London: Random Century, 1992

Kelsen, Hans. Pure Theory of Law, Legality and Legitimacy, Oxford: Oxford University Press. 2007

Maimonides. Introduction to the Talmud, Trans, and Annot. Z Lampel. New York: Judaica Press. 1975

McMillan, John, Evans Gareth and Haddon Storey. Australia's Constitution: Time for Change?. Sydney:Law Foundation of New South Wales and George Allen \& Unwin Australia. 1983

Quick, John and Garran, Robert. The Annotated Constitution of the Australian Common $\neg$ wealth, 3rd ed. Sydney: Angus and Robertson. 1995

Zines, Leslie. Constitutional Change in the Commonwealth. Cambridge: Cambridge University Press. 1991

\section{Journal}

Cover, Robert M. "Obligation: a Jewish jurisprudence of the social order." Journal of Law and Religion 5, no. 1 (1987): 65-74.

Cunneen, Chris, Fiona Allison, and Melanie Schwartz. "Access to justice for Aboriginal People in the Northern Territory." Australian Journal of Social Issues 49, no. 2 (2014): 219-240. http://doi.org/10.1002/j.1839-4655.2014.tb00309.x

Dane, Perry. "The Yoke of Heaven, The Question of Sinai, and the Life of Law." The University of Toronto Law Journal 44, no. 4 (1994): 353-400. 
Dainow, Joseph. "The civil law and the common law: Some points of comparison." The American Journal of Comparative Law 15, no. 3 (1966): 419-435. http:// www.jstor.org/stable/838275?seq=1\#page_scan_tab_contents

Elon, Menachem. “The Legal System of Jewish Law.” NYUJ Int'l L. \& Pol. 17 (1984): 221.

Elon, Menachem. "Law, Truth, and Peace: The Three Pillars of the World." NYUJ Int'l L. \& Pol. 29 (1996): 439.

Gaymarani, George Pascoe. "An Introduction to the Ngarra Law of Arnhem Land". Northern Territory Law Journal1 (2011): 283-304.

Hands, Tatum. "Teaching an Old Dog New Tricks: Recognition of Aboriginal Customary Law in Western Australia." Indigenous Law Bulletin 6, no. 17 (2006): 12-15.

Kelly, Danial. "The Black and White of Wunungmurra", Northern Territory Law Journal 2 (2012): 227-235.

Kelly, Danial. "Foundational Sources and Purposes of Authority in Madayin." Victoria UL \& Just. J. 4 (2014): 33.

Kelly, Danial. "The Legal and Religious Nature of Aboriginal Customary Law: Focus on Madayin." U. Notre Dame Austl. L. Rev. 16 (2014): 50-73.

Lindell, Geoffrey J. "Why Is Australia's Constitution Binding-The Reasons in 1900 and Now, and the Effect of Independence." FL Rev. 16 (1986): 29.

Lindell, G. J. "Expansion or Contraction-Some Reflections about the Recent Judicial Developments on Representative Democracy." Adel. L. Rev. 20 (1998): 111-146.

Luban, David."The Coiled Serpent of Argument: Reason, Authority, and Law in A Talmudic Tale", Chicago-Kent Law Review79 (2004):1253-1288.

Mattei, Ugo. "Three Patterns of Law: Taxonomy and Change in The World's Legal Systems." The American journal of comparative law 45, no. 1 (1997): 5-44.

McKenna, Mark, Amelia Simpson, and George Williams. "First words: The Preamble to the Australian Constitution." UNSWLJ 24 (2001): 382.

Sieder, Rachel. "The Challenge of Indigenous Legal Systems: Beyond Paradigms of Recognition." The Brown Journal of World Affairs 18, no. 2 (2012): 103-114. 
Sinai, Yuval. "Reconsidering Res Judicata: A Comparative Perspective." Duke J. Comp. \& Int'l L. 21, no. 2 (2010): 353-400. https://scholarship.law.duke. $\mathrm{edu} / \mathrm{djcil} / \operatorname{vol} 21 / \mathrm{iss} 2 / 3$

\section{Legal Document}

Australian Constitution

Foundations of Law 5740-1980, Sefer Ha-Chukim No. 978 at 163 (July 31, 1980)

International Covenant on Economic, Social and Cultural Rights, adopted 16 Dec. 1966, G.A. Res. 2200 (XXI), U.N. GAOR, 21st Sess., art. 2(2), U.N. Doc. A/6316 (1966), 993 U.N.T.S. 3 (entered into force 3 Jan. 1976)

United Nations Declaration on the Rights of Indigenous People annexed to GA Res 61/295, UNGAOR 61

\section{Other Document}

Australian Law Reform Commission. "Recognition of Aboriginal Customary Laws". Report No. 31. 12 June 1986.

Berndt, Ronald M."A Profile of Good and Bad in Australian Aboriginal Religion”. Charles Strong Memorial Lecture 1979 reprinted from Colloquium Journal of the Australian and New Zealand Society for Theological Studies.

Calma, Tom." Sustaining Indigenous Education, Language and Culture."Speech delivered at World Indigenous People's Conference: Education on 9 December 2008.

International Law Association. The Hague Conference (2010) Rights of Indigenous Peoples 74 International Law Association Report Conference. 8342010.

Richards. Kelly, Police-referred Restorative Justice for Juveniles in Australia [online]. Trends and Issues in Crime and Criminal Justice, No. 398, Aug 2010: [1]-8. http: / / search.informit.com.au.ezproxy.cdu.edu.au/documentSummary; dn=8 46094200631694;res=IELHSS.

Simpson, Amelia and George Williams."International Law and Constitutional Interpretation". 11 PLR 205.

\section{Case Law}

Al-Kateb v Godwin (2004) 219 CLR 562 
Bugmy v The Queen (2013) 249 CLR 571; [2013] HCA 37

CPCF v Minister for Immigration and Border Protection [2015] HCA 1

Humane Society International Inc v Minister for the Environment and Heritage (2003) 126 FCR 205

Kruger v Commonwealth (1997) 190 CLR 1

Mabo v Commonwealth (1992) 175 CLR 1

Mabo v Queensland (No 2) (1992) 175 CLR

Minister for Immigration and Ethnic Affairs $v$ Teoh (1995) 183 CLR 273

Milpurrurru $v$ Indofurn Pty Ltd (1995) 6 AIPJ 185

Theophanous $v$ Herald and Weekly Times (1994) 182 CLR 104

$R v$ Jack Congo Murrell (1836) 1 Legge 72

$R v$ Wunungmurra (2009) 196 A Crim R 166

Wik Peoples $v$ Queensland (1996) 187 CLR 1

\section{Website Content/Internet}

Encyclopaedic Australian Legal Dictionary. http:/ /www.lexisnexis.com.ezproxy.cdu. edu.au/au/legal/results / enhdocview.do?docLinkInd=true\&ersKey=23_T 25738853566\&format $=$ GNBFULL\&startDocNo=0\&results UrlKey=0_ T25738853569\&backKey=20_T25738853570\&csi $=267785 \& d o c N o=2 \&$ from DocPreview $=$ true $\&$ scrollToPosition $=0$

Jewish Virtual Library. "Encyclopedia Judaica, Practice and Procedure." http:// www.jewishvirtuallibrary.org/practice-procedure 